\title{
APPROACHES TO ASSESSMENT OF HOT ENVIRONMENT
}

\author{
Kralikova, R.; SoKOlOVA, H.; WeSSEly, E. \& PolaK, J.
}

Abstract: Average person spends about one third of day at work. During working hours in industrial workplaces, workers can be exposed to possible heat and cold risks. A significant thermo-humidity microclimate in such workplaces is created by technological equipment. Thermo-hygric microclimate evaluation in workplaces is therefore very important and obtained results should lead to reduction of thermal loads on workers. The need of quick thermal environment assessment based on a few measurements and calculations has led into application of indices in thermal comfort assessment. The most used empirical index for assessment of hot stress potential is WBGT index (wet bulb globe temperature). WBGT index is the most used and accepted index for the assessment of heat stress in industry. The paper deals with workplace monitoring of hot microclimate where workers are exposed to hot stress which was assessed by WBGT index.

Key words: hot environment, thermo-humidity microclimate, evaluation, stress
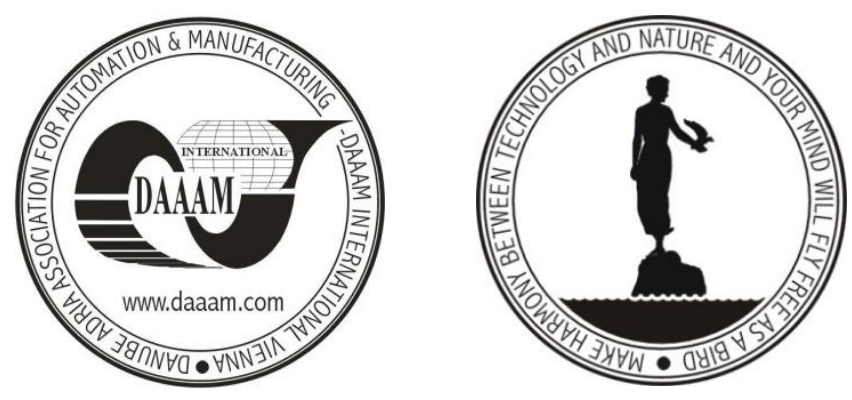

Authors' data: Doc. Ing. Kralikova, R[uzena]"; Ing. Sokolova H[ana]"; Doc. Ing. Wessely E[mil] ${ }^{* *}$; Ing. Polak J[an $]^{* * *},{ }^{*}$ Department of environmentalistics, Faculty of Mechanical Engineering, Technical University of Kosice, Park Komenskeho 5, 04201 Kosice, ${ }^{* *}$ University of Security Management in Košice, ${ }^{* * *}$ Faculty of Electrical Engineering and Informatics, Technical University of Kosice, Letná 9, 042 00 Košice, Slovakia., ruzena.kralikova@tuke.sk, hana.sokolova@tuke.sk, polakjano@gmail.com

This Publication has to be referred as: Kralikova, R[uzena]; Sokolova, H[ana]; Wessely, E[mil] \& Polak, J[an] (2013) Approaches to Assessment of Hot Environment, Chapter 14 in DAAAM International Scientific Book 2013, pp. 317 328, B. Katalinic \& Z. Tekic (Eds.), Published by DAAAM International, ISBN 9783-901509-94-0, ISSN 1726-9687, Vienna, Austria

DOI: $10.2507 /$ daaam.scibook.2013.14 
Kralikova, R.; Sokolova, H.; Wessely, E. \& Polak, J.: Approaches to Assessment of...

\section{Introduction}

Reliable assessment of thermo-hygric microclimate should take into consideration all six primary factors affecting thermal comfort i.e. air temperature, radiation, relative humidity, air velocity, thermo-physical properties of clothing and metabolic rate. One way of how to evaluate thermal environment is the use of thermal comfort indices, which combines two or more parameters of thermo-hygric microclimate in one variable. There are several thermal comfort indices for evaluation of different thermal environments (ASHRAE, 2009).

\section{View of Indices for Assessment of Different Thermal Environments}

One way of how to evaluate thermal environment is to use thermal comfort indices, which combines two or more parameters of thermal microclimate into one variable. Indices can be divided into (Auliciems, 2007):

- Analytical indices - based on theoretical concepts,

- Empirical indices - based on object measurements or on simplified relationships that do not necessarily follow a theory.

Indicators can be also divided according to class into which the thermal environment is addressed to: moderate, hot and cold environment (Fig.1).

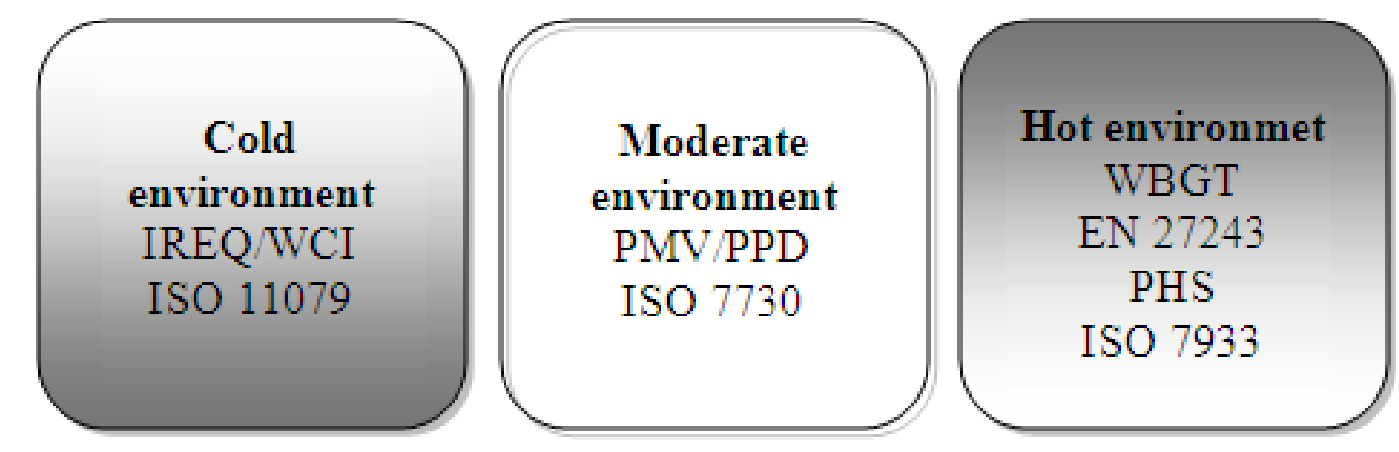

Fig.1. Indices for assessing of different thermal environments (d'AMBROSIO ALFANO, 2011)

ISO organization has created a number of important standards which are dealing with categories used by thermal environment indices:

- IREQ - refers to minimum clothing insulation required by workers. The index is used for calculation of clothing ensemble and was applied as an initial attempt at providing thermal comfort. This index represents a method to calculate the thermal stress associated with the exposure to cold environments.

- WCI - Wind Chill Index is the equivalent to perceived temperature that measures the additional loss of thermal comfort of the human body due to the wind (especially) in winter outdoor conditions. 
- PMV - Predicted Mean Vote Index. The index predicts the mean response of a larger group of people according to the ASHRAE thermal sensation scale where: +3 hot, +2 warm, +1 slightly warm, 0 neutral, -1 slightly cool, -2 cool, -3 cold (Fig. 2). The PMV index was expressed by P.O. Fanger as:

$$
\mathrm{PMV}=\left(0.303 \mathrm{e}^{-0,036 \mathrm{M}}+0.028\right) \mathrm{L}
$$

where: $\quad \mathrm{M}$ - metabolic rate,

$\mathrm{L}$ - thermal load - defined as the difference between the internal heat production and the heat loss to the actual environment - for a person at comfort skin temperature and evaporative heat loss by sweating at the actual activity level.

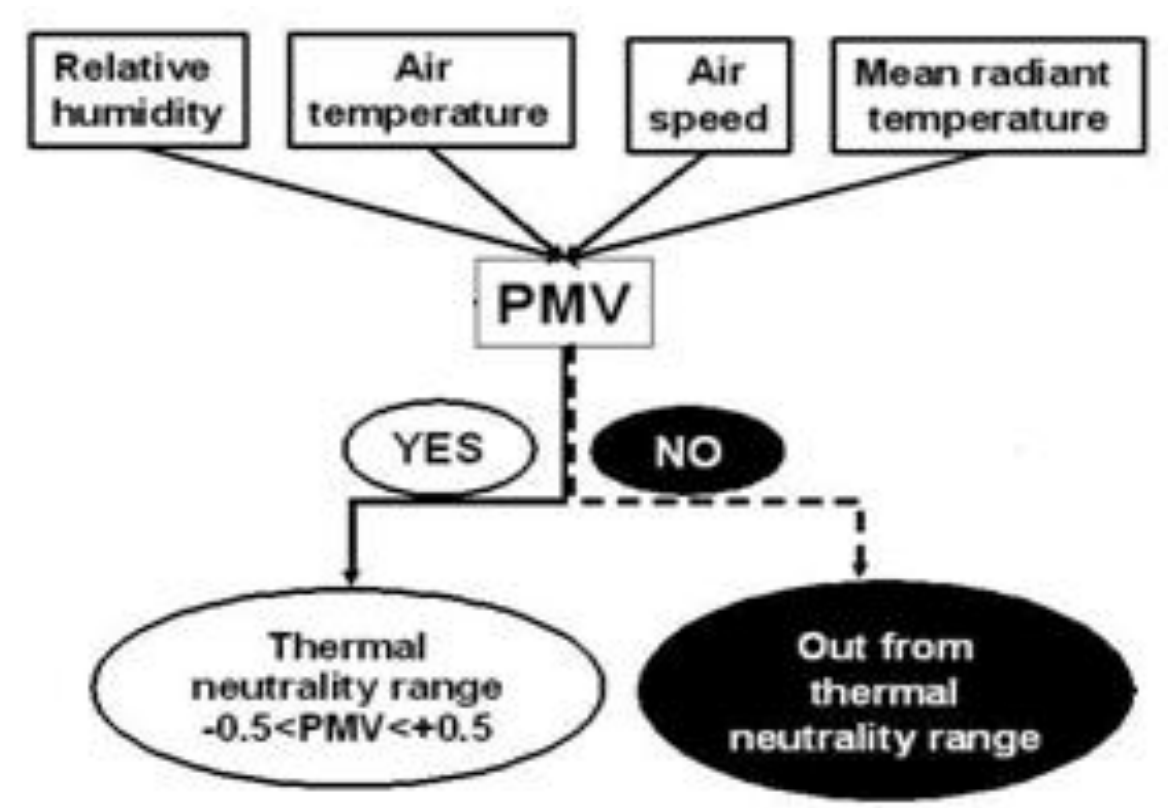

Fig. 2. Assessment Predicted Mean Vote

- PPD index (Predicted Percentage Dissatisfied) is a quantitative measure of the thermal comfort of a group of people at a particular thermal environment. At least approx. $5 \%$ of people in a group will be dissatisfied with the thermal climate - even with PMV = 0, see Fig. 3.

- The Wet Bulb Globe Temperature (WBGT) is a composite temperature used to estimate the effect of temperature, humidity and solar radiation on humans. The three elements $\mathrm{Tw}, \mathrm{Tg}$, and $\mathrm{Ta}$ are combined into a weighted average to produce the WBGT (EN 27243, 1998). The temperatures may be in either Celsius or Fahrenheit.

$$
\text { WBGT }=(0.7 \times \mathrm{Tw})+(0.2 \times \mathrm{Tg})+(0.1 \times \mathrm{Ta})
$$

Indoors, or when solar radiation is negligible, the following formula is used: 
Kralikova, R.; Sokolova, H.; Wessely, E. \& Polak, J.: Approaches to Assessment of...

$$
\text { WBGT }=(0.7 \times \mathrm{Tw})+(0.3 \times \mathrm{Tg})
$$

- PHS (Predicted Heat Strain) index is a rational index, based on the thermal balance equation which uses measured environmental parameters in a series of equations to predict the body response to the heat stress as a raise in core temperature.

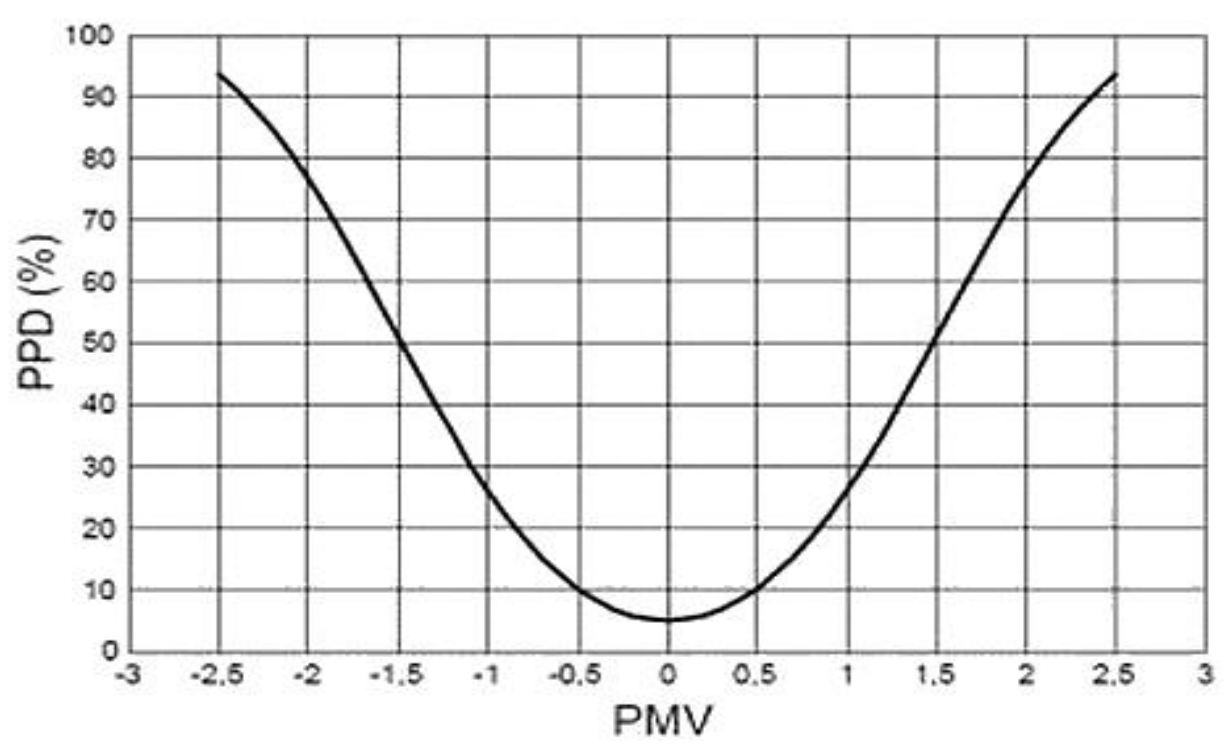

Fig. 3. Evolution of PPD on the basis of PMV

\section{Practical Measurement of Thermal Microclimate}

Monitoring of thermo-hygric microclimate was carried out using the Testo 400, to which tri-functional probe was attached, three-level globe Vernon-Jokl thermometer, and WBGT set. Used equipment meets ISO 7726 requirements for accuracy. Based on the movement of workers during their work shift, two measuring points were selected. These most frequent places were then monitored for 6 hours. Along with measuring points, activities of workers were also analyzed and later served in overall evaluation of the measurement. Because there are two major sources of radiant heat in operation, variable air speed and people moving freely, environment was evaluated as a heterogeneous and non-stationary. Therefore it was necessary to perform measurements at three levels: head $(1.7 \mathrm{~m})$, abdomen $(1.1 \mathrm{~m})$, ankles $(0.1 \mathrm{~m})$. Results obtained from two measurement points were put into table and basic statistic was implied in calculation.

Outside climatic situation of workplace is also a part of the monitoring of thermo-hygric microclimate. During the measurement there was a sunny day and the outdoor air temperature was between 29 and $34\left[{ }^{\circ} \mathrm{C}\right]$. Relative humidity was about 40 $[\%]$ and air velocity was about $6\left[\mathrm{~m} \cdot \mathrm{s}^{-1}\right]$. 


\subsection{Experimental Measurements of Thermal-moisture Microclimate}

Three basic physical quantities of thermo-hygic microclimate were measured $\mathrm{R}_{\mathrm{h}}$ relative humidity [\%], the dry air temperature $\mathrm{t}_{\mathrm{a}}\left[{ }^{\circ} \mathrm{C}\right]$ and air velocity $\mathrm{v}_{\mathrm{a}}\left[\mathrm{m} \cdot \mathrm{s}^{-1}\right]$ with measuring device Testo 400. Measurements took place in 2 measuring locations M1 and M2 during 6 hours. Measured values of thermo-hygric microclimate were processed in MS Excel. Basic statistical functions such as: min (the lowest value of the set of values), max (maximum value of the set of value,, average (arithmetic mean arguments), stdev (standard deviation), median (middle value of a group of numbers), var (variance values), mode (most frequently occurring value in a group of numbers) were used.

\begin{tabular}{|c|c|c|c|c|c|c|c|c|c|}
\hline \multirow{2}{*}{ Function } & \multicolumn{3}{|c|}{$\mathbf{R}_{\mathrm{h}}[\%]$} & \multicolumn{3}{|c|}{$\mathbf{t}_{\mathrm{a}}\left[{ }^{\circ} \mathbf{C}\right]$} & \multicolumn{3}{|c|}{$\mathbf{v}_{\mathbf{a}}[\mathrm{m} / \mathrm{s}]$} \\
\hline & Head & Abdomen & Ankles & Head & Abdomen & Ankles & Head & Abdomen & Ankles \\
\hline $\min$ & 33,1 & 32,7 & 33,6 & 31,1 & 30,4 & 29,7 & 0,18 & 0,14 & 0,18 \\
\hline $\max$ & 43,1 & 42,6 & 42,8 & 36,2 & 34,7 & 33,7 & 0,46 & 0,41 & 0,36 \\
\hline average & 39,07 & 36,75 & 37,70 & 32,98 & 32,82 & 32,07 & 0,28 & 0,27 & 0,27 \\
\hline stdev & 3,02 & 2,99 & 2,34 & 1,38 & 1,2 & 1,29 & 0,05 & 0,05 & 0,04 \\
\hline median & 39,65 & 36,9 & 37,35 & 33 & 32,4 & 32,5 & 0,28 & 0,27 & 0,27 \\
\hline var & 9,15 & 8,91 & 5,48 & 1,89 & 1,44 & 1,67 & 0,002 & 0,002 & 0,001 \\
\hline mode & 41,4 & 38,7 & 34,9 & 33,2 & 32,1 & 29,7 & 0,28 & 0,29 & 0,25 \\
\hline \multirow{2}{*}{$\begin{array}{c}\text { Mean } \\
\text { value } \\
\Phi\end{array}$} & \multicolumn{3}{|c|}{$\Phi_{\mathrm{Rh}}[\%]$} & \multicolumn{3}{|c|}{$\boldsymbol{\Phi}_{\mathrm{ta}}\left[{ }^{\circ} \mathbf{C}\right]$} & \multicolumn{3}{|c|}{$\Phi_{\mathrm{va}}[\mathrm{m} / \mathrm{s}]$} \\
\hline & \multicolumn{3}{|c|}{37,57} & \multicolumn{3}{|c|}{32,67} & \multicolumn{3}{|c|}{0,27} \\
\hline
\end{tabular}

Tab. 1. Statistical processing of the measured values on workplace M1

\begin{tabular}{|c|c|c|c|c|c|c|c|c|c|}
\hline \multirow{2}{*}{ Function } & \multicolumn{3}{|c|}{$\mathbf{R}_{h}[\%]$} & \multicolumn{3}{|c|}{$\mathbf{t}_{\mathbf{a}}\left[{ }^{\circ} \mathbf{C}\right]$} & \multicolumn{3}{|c|}{$\mathbf{v}_{\mathbf{a}}[\mathrm{m} / \mathrm{s}]$} \\
\hline & Head & Abdomen & Ankles & Head & Abdomen & Ankles & Head & Abdomen & Ankles \\
\hline $\min$ & 33,7 & 32,8 & 33,5 & 33,2 & 33 & 25,4 & 0,12 & 0,01 & 0,15 \\
\hline $\max$ & 43,6 & 38,5 & 40,4 & 34,9 & 34,3 & 34,3 & 0,31 & 0,4 & 0,66 \\
\hline average & 38,29 & 36,02 & 36,5 & 33,95 & 33,69 & 33,06 & 0,23 & 0,22 & 0,26 \\
\hline stdev & 2,28 & 1,71 & 1,67 & 0,54 & 0,41 & 1,6 & 0,04 & 0,08 & 0,11 \\
\hline median & 37,95 & 36,45 & 36,9 & 33,8 & 33,5 & 33,25 & 0,23 & 0,23 & 0,23 \\
\hline var & 5,2 & 2,93 & 2,8 & 0,29 & 0,17 & 2,4 & 0,002 & 0,01 & 0,01 \\
\hline mode & 36,9 & 37,5 & 37,6 & 33,9 & 33,4 & 33,3 & 0,26 & 0,23 & 0,23 \\
\hline \multirow{2}{*}{$\begin{array}{c}\text { Mean value } \\
\Phi\end{array}$} & \multicolumn{3}{|c|}{$\boldsymbol{\Phi}_{\mathrm{Rh}}[\%]$} & \multicolumn{3}{|c|}{$\Phi_{\mathrm{ta}}\left[{ }^{\circ} \mathbf{C}\right]$} & \multicolumn{3}{|c|}{$\Phi_{\mathrm{va}}[\mathrm{m} / \mathrm{s}]$} \\
\hline & \multicolumn{3}{|c|}{36,71} & \multicolumn{3}{|c|}{33,6} & \multicolumn{3}{|c|}{0,23} \\
\hline
\end{tabular}

Tab. 2. Statistical processing of the measured values on workplace M2

Measured values of dry air temperature, air velocity and relative humidity at both measuring points and at all three levels were statistically processed in MS Excel program. Graphical processing of data obtained by measuring of Testo 400 is shown 
Kralikova, R.; Sokolova, H.; Wessely, E. \& Polak, J.: Approaches to Assessment of...

on the Figure 4 and 5. On the horizontal axis measuring time is shown while on vertical axis are values of dry air temperature, air flow velocity and the relative humidity.

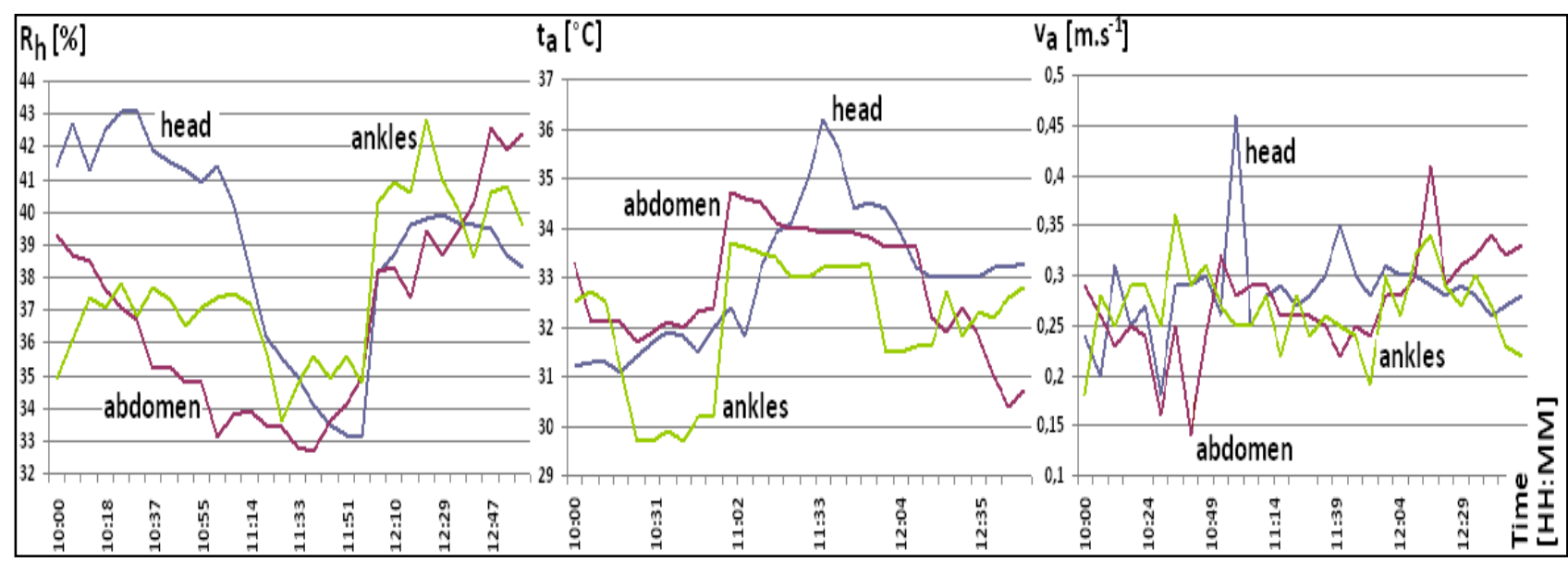

Fig. 4. Development of the relative humidity $\left(\mathrm{R}_{\mathrm{h}}\right)$, air temperature $\left(t_{\mathrm{a}}\right)$ and air velocity $\left(\mathrm{v}_{\mathrm{a})}\right.$ on place $\mathrm{M} 1$

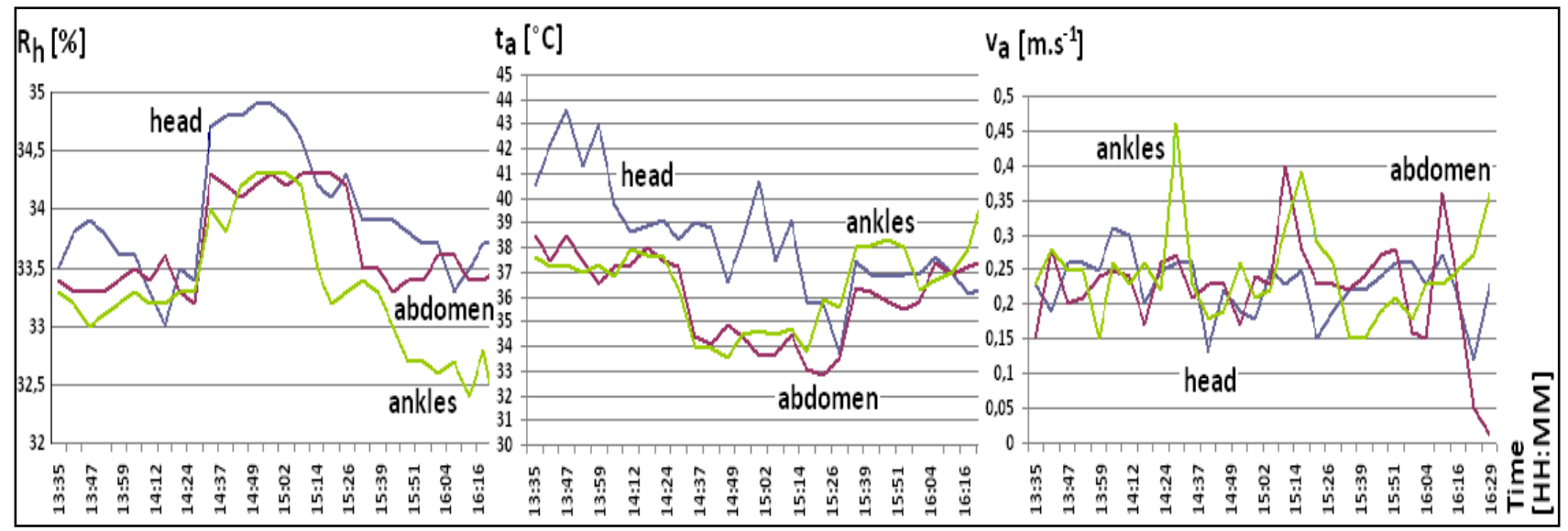

Fig. 5. Development of the relative humidity $\left(\mathrm{R}_{\mathrm{h}}\right)$, air temperature $\left(t_{\mathrm{a}}\right)$ and air velocity $\left(\mathrm{v}_{\mathrm{a}}\right)$ on place $\mathrm{M} 2$

\subsection{Globe Temperature}

Temperature measurement obtained by globe thermometer was conducted in order to determine the approximate amount of mean temperature radiation $\mathrm{t}_{\mathrm{r}, \mathrm{m}}\left[{ }^{\circ} \mathrm{C}\right]$ by using the three level Vernon-Jokl thermometer. Black ball thermometer is used to derive the approximate value of mean temperature radiation from the observed simultaneous temperatures readings of globe temperature $\left(\mathrm{t}_{\mathrm{g}}\right)\left[{ }^{\circ} \mathrm{C}\right]$, air temperature and air velocity surrounding the sphere (Auliciems, Szokolay, Steven, 2007). Measurements done with this device were conducted at 2 measuring locations during working shift. The values of global temperature, measured by Vernon-Jokl were statistically processed. Graphical processing of data obtained by measuring of global temperature can be seen in Figure 6. and 7. On the horizontal axis measuring time is shown while on vertical axis the final temperature of the globe temperature is shown. 


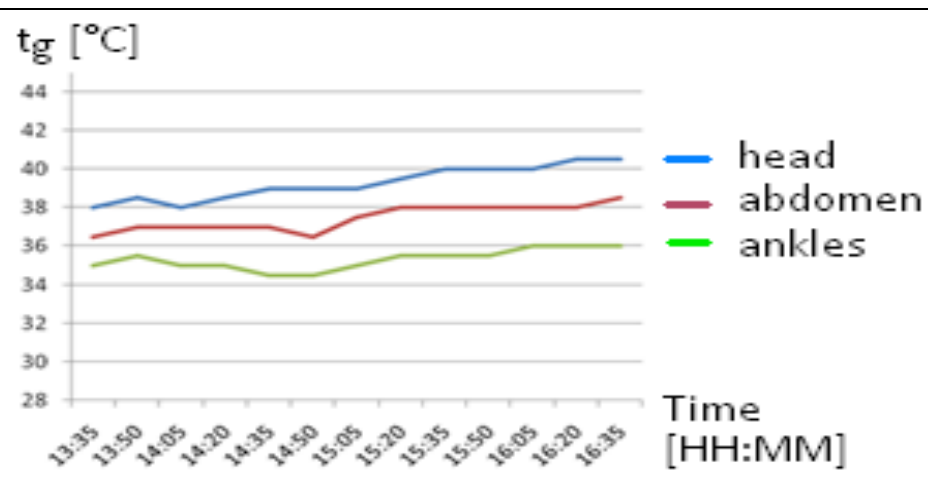

Fig. 6. Development of the globe temperature on workplace M1

\begin{tabular}{|c|c|c|c|c|}
\hline Function & $\mathbf{t}_{\mathrm{g} \text { head }}\left[{ }^{\circ} \mathbf{C}\right]$ & $\mathbf{t}_{\mathrm{g} \text { abdomen }}\left[{ }^{\circ} \mathbf{C}\right]$ & $\mathbf{t}_{\mathbf{g} \text { ankles }}\left[{ }^{\circ} \mathbf{C}\right]$ & $\begin{array}{c}\text { Mean value } \\
\boldsymbol{\Phi t}_{\mathrm{g}}\left[{ }^{\circ} \mathrm{C}\right]\end{array}$ \\
\hline \multicolumn{4}{|c|}{ Measuring point M1 } & M1 \\
\hline $\min$ & 34 & 33 & 31,5 & \multirow{7}{*}{37,38} \\
\hline $\max$ & 37,5 & 36,5 & 35 & \\
\hline average & 35,65 & 34,69 & 33,39 & \\
\hline stdev & 1,25 & 1,23 & 1,33 & \\
\hline median & 35,5 & 34,5 & 33 & \\
\hline var & 1,56 & 1,52 & 1,76 & \\
\hline mode & 37 & 36 & 35 & \\
\hline \multicolumn{4}{|c|}{ Measuring point M2 } & \multirow{8}{*}{34,61} \\
\hline $\min$ & 38 & 36,5 & 34,5 & \\
\hline $\max$ & 40,5 & 38,5 & 36 & \\
\hline average & 39,27 & 37,46 & 35,31 & \\
\hline stdev & 0,88 & 0,66 & 0,52 & \\
\hline median & 39 & 37,5 & 35,5 & \\
\hline var & 0,78 & 0,44 & 0,27 & \\
\hline mode & 39 & 38 & 35 & \\
\hline
\end{tabular}

Tab. 3. Statistical processing of the measured values

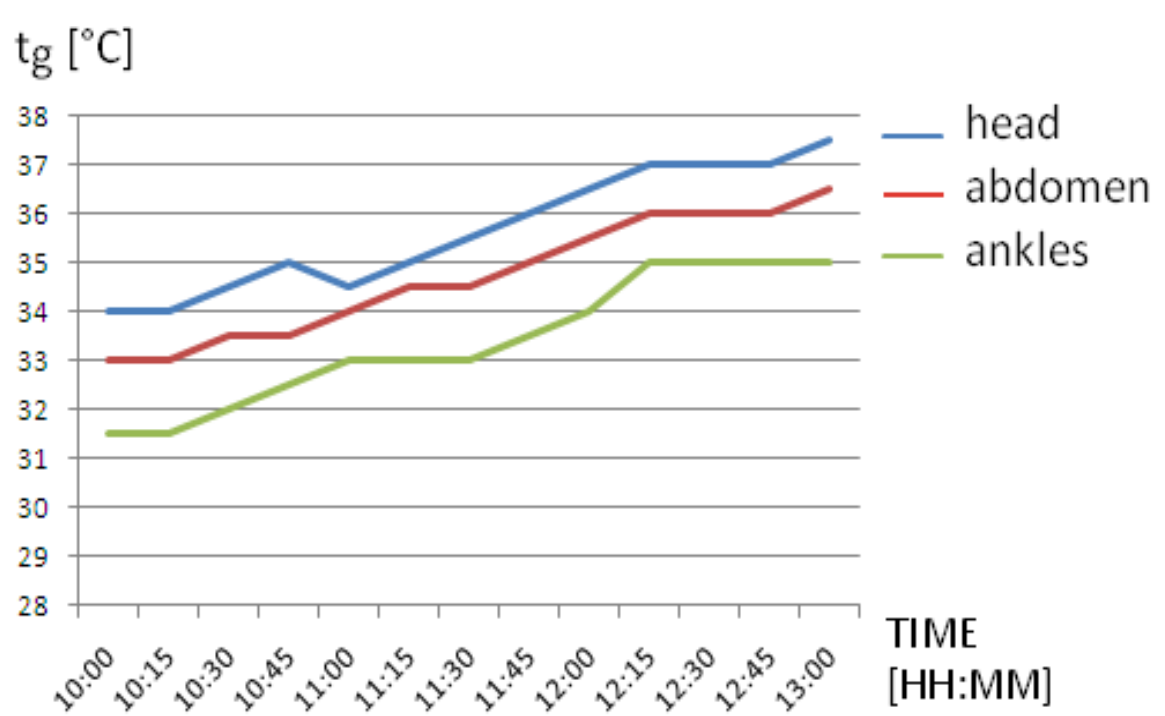

Fig. 7. Development of the globe temperature on workplace M2 
Kralikova, R.; Sokolova, H.; Wessely, E. \& Polak, J.: Approaches to Assessment of...

\subsection{WBGT Sensor}

The values of WBGT index were obtained by device with WBGT sensor. Measurement was conducted on two measuring places (M1, M2) during 6 hour work shift. During the whole measurement there was 30 minute time used for setting the sensor. Variables such as: black globe temperature $t_{\mathrm{r}}\left[{ }^{\circ} \mathrm{C}\right]$, wet bulb temperature $\mathrm{t}_{\mathrm{w}}$ $\left[{ }^{\circ} \mathrm{C}\right]$ and dry bulb temperature $\mathrm{t}_{\mathrm{a}}\left[{ }^{\circ} \mathrm{C}\right]$ were measured by this device. Measured values from WBGT sensor were statistically and graphically processed in MS Excel (see Fig. 8 and 9). On the horizontal axis measuring time is shown while on vertical axis is temperature in $\left[{ }^{\circ} \mathrm{C}\right]$.

\begin{tabular}{|c|c|c|c|c|}
\hline \multicolumn{5}{|c|}{ Measuring point M1 } \\
\hline Function & $\mathbf{t}_{\mathbf{r}}\left[{ }^{\circ} \mathbf{C}\right]$ & $\mathbf{t}_{\mathbf{w}}\left[{ }^{\circ} \mathbf{C}\right]$ & $\mathbf{t}_{\mathbf{a}}\left[{ }^{\circ} \mathbf{C}\right]$ & WBGT $\left[{ }^{\circ} \mathbf{C}\right]$ \\
\hline min & 32 & 29,9 & 29,6 & 30,8 \\
\hline max & 37 & 34,4 & 36,7 & 35,1 \\
\hline average & 35,38 & 32,29 & 33,53 & 33,22 \\
\hline stdev & 0,94 & 0,84 & 1,32 & 0,86 \\
\hline median & 35,7 & 32,6 & 33,8 & 33,5 \\
\hline var & 0,88 & 0,7 & 1,74 & 0,74 \\
\hline mode & 35,8 & 32,7 & 33,9 & 33,6 \\
\hline \multicolumn{5}{|c|}{ Measuring point $\mathbf{M 2}$} \\
\hline Function & $\mathbf{t}_{\mathbf{r}}\left[{ }^{\circ} \mathbf{C}\right]$ & $\mathbf{t}_{\mathbf{w}}\left[{ }^{\circ} \mathbf{C}\right]$ & $\mathbf{t}_{\mathbf{a}}\left[{ }^{\circ} \mathbf{C}\right]$ & $\mathbf{W B G T}\left[{ }^{\circ} \mathbf{C}\right]$ \\
\hline min & 34,4 & 31,1 & 33 & 32,1 \\
\hline max & 35,9 & 32,6 & 34,6 & 33,6 \\
\hline average & 35,07 & 31,89 & 33,76 & 0,33 \\
\hline stdev & 0,34 & 0,33 & 0,36 & 32,8 \\
\hline median & 35,1 & 31,9 & 33,8 & 0,11 \\
\hline var & 0,12 & 0,11 & 0,13 & 32,8 \\
\hline mode & 35,1 & 31,8 & 33,8 & \\
\hline
\end{tabular}

Tab. 4. Statistical processing of the measured WBGT values

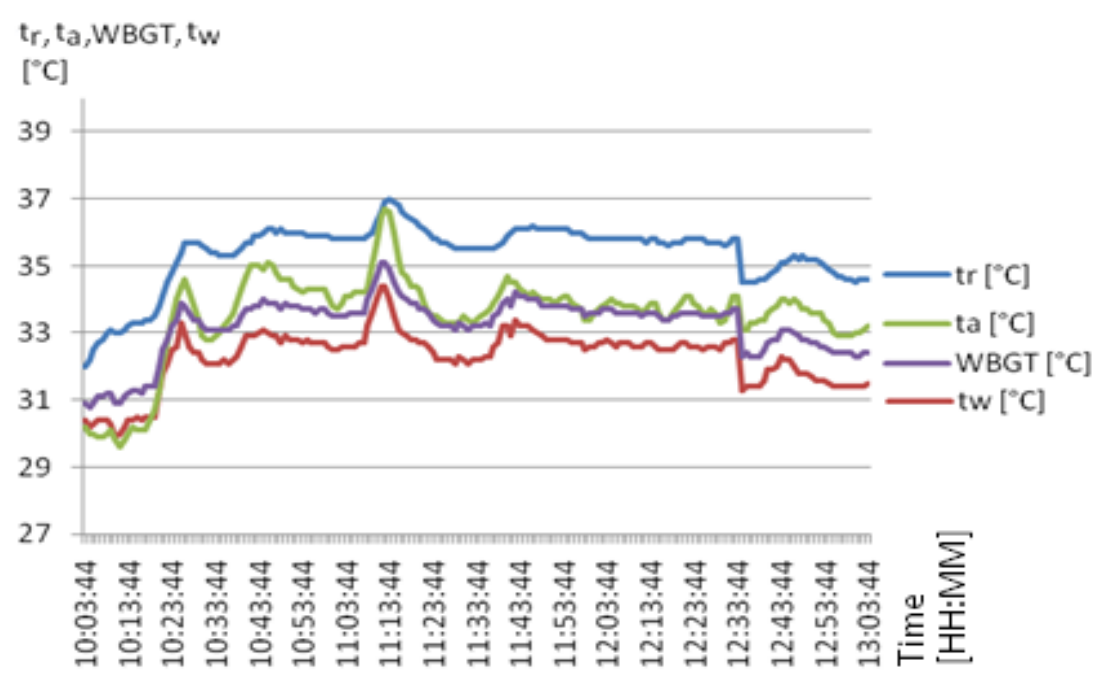

Fig. 8. Development of values measured by WBGT sensor on M1 


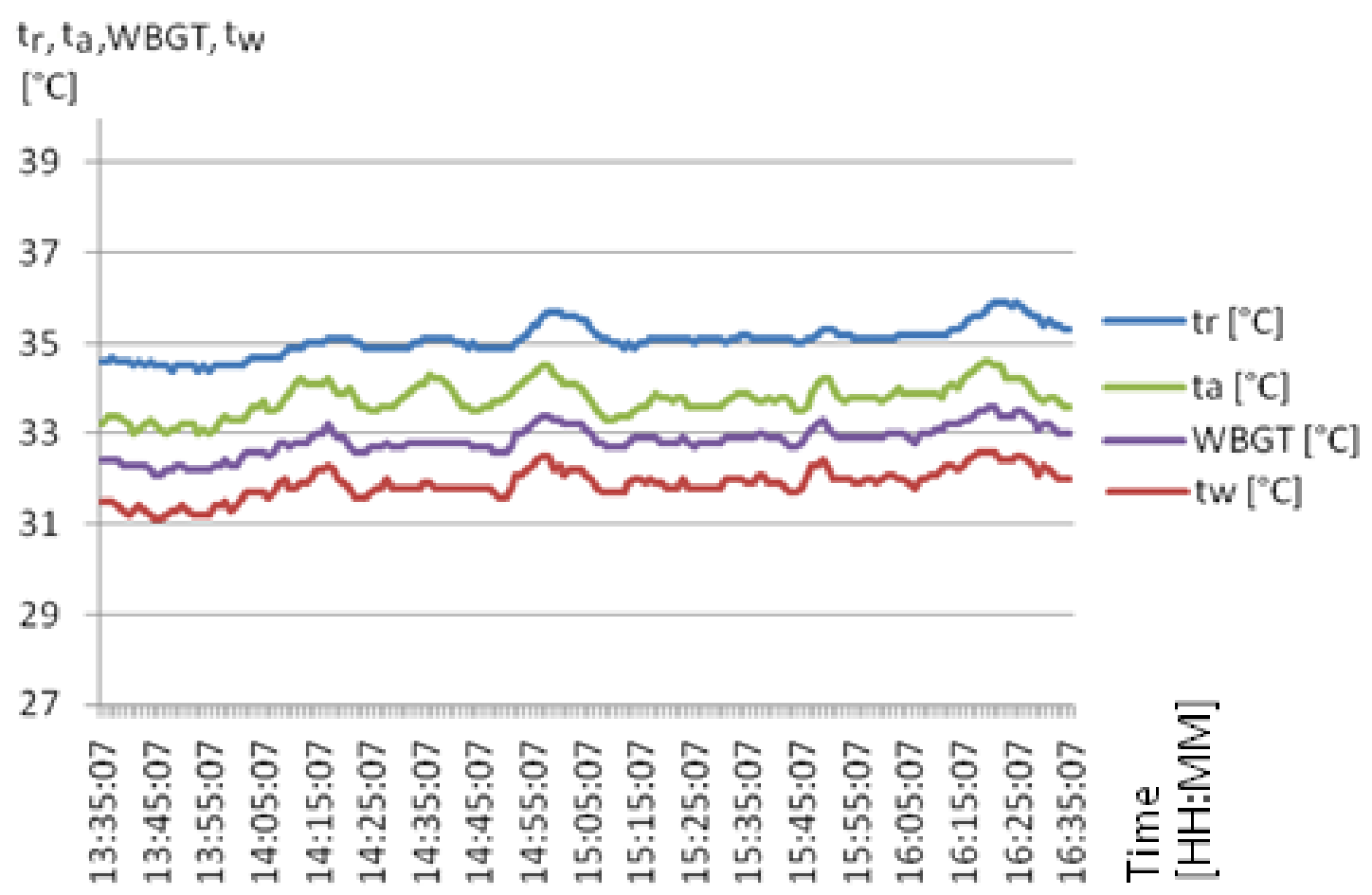

Fig. 9. Development of values measured by WBGT sensor on M2

\section{Processing of Evaluation}

Evaluation was done by calculating the mean radiant temperature, PMV index, the determination of metabolic rate and thermal insulation of workers clothing.

\subsection{Determination of the mean Radiant Temperature}

Mean radiant temperature $t_{r, m i}$ was determined by calculation of the mean radiant temperature measured of black ball for both measured points (Table 1), taking into account that evaluated workplace is a class Stress environment (see equation no. 4) (ISO 7726, 2003):

$$
t_{m i j}=\frac{t_{r, m i, j}+2 \cdot t_{r, m i, j}+t_{r, m i, j}}{4}\left[{ }^{\circ} \mathrm{C}\right]
$$

where: $\quad \mathrm{t}_{\mathrm{rm} i, j}\left[{ }^{\circ} \mathrm{C}\right] \quad-$ mean radiant temperature,

$i \quad-$ horizontal measurement places,

$j \quad-$ vertical level $(0.1 \mathrm{~m} ; 1.1 \mathrm{~m} ; 1.7 \mathrm{~m})$.

Mean radiant temperature $\left(\operatorname{tr}_{m i, j}\right)$ for certain levels for measurement places were calculated from equation (5):

$$
t_{r, m_{i, j}}=\left[\left(t_{g_{i, j}}+273\right)^{4}+\frac{1,1 \cdot 10^{8} \cdot v_{a, j}^{0,6}}{\varepsilon_{g} \cdot D^{0,4}} \cdot\left(t_{g_{i, j}}-t_{a i, j}\right)\right]^{1 / 4}-273\left[{ }^{\circ} \mathrm{C}\right]
$$


Kralikova, R.; Sokolova, H.; Wessely, E. \& Polak, J.: Approaches to Assessment of...

where: $\quad \mathrm{t}_{\mathrm{gi}, \mathrm{j}}\left[{ }^{\circ} \mathrm{C}\right] \quad-$ mean value of black ball temperature for given levels of measurement,

$\mathrm{v}_{\mathrm{ai}, \mathrm{j}}\left[\mathrm{m} \cdot \mathrm{s}^{-1}\right]$ - speed of airflow for given levels of measurement,

$\varepsilon_{\mathrm{g}}[-] \quad-$ black ball emissivity, $\varepsilon_{\mathrm{g}}=0,95$ (matte black surface),

$\mathrm{D}[\mathrm{m}] \quad-$ ball diameter.

\begin{tabular}{|c|c|c|c|c|c|c|c|}
\hline \multicolumn{3}{|c|}{ WORKPLACE M1 } & \multicolumn{4}{c|}{ WORKPLACE M2 } \\
\hline $\mathrm{t}_{\mathrm{rm} 1,1}$ & $\mathrm{t}_{\mathrm{r}, \mathrm{m} 1.2}$ & $\mathrm{t}_{\mathrm{r}, \mathrm{m} 1.3}$ & $\mathrm{t}_{\mathrm{r}, \mathrm{m} 1}$ & $\mathrm{t}_{\mathrm{r}, \mathrm{m} 2.1}$ & $\mathrm{t}_{\mathrm{rm} 2.2}$ & $\mathrm{t}_{\mathrm{r}, \mathrm{m} 2.3}$ & $\mathrm{t}_{\mathrm{r}, \mathrm{m} 2}$ \\
\hline 37,88 & 36,80 & 34,90 & 36,60 & 44,40 & 41,09 & 37,77 & 41,09 \\
\hline
\end{tabular}

Tab. 5. The mean radiant temperature values for M1 and M2

\subsection{Computer program for Calculating Predicted Mean Vote (PMV) and Predicted Percentage of Dissatisfied (PPD)}

PMV can be used to verify if the thermal environment satisfy thermal comfort criteria. PMV is calculated from temperature, mean radiant temperature, air velocity, humidity, energy expenditure and the thermal resistance of clothing (ISO 7730, 2006).

Program syntax for PMV and PPD can be found in ISO 7730. Program was rewritten in Java programming language. Thermal clothing insulation and metabolic rate was needed for the calculation.

Thermal clothing insulation $\left(\mathrm{I}_{\mathrm{cl}}\right)$ was calculated according to the different types of clothes stated in ISO 7730. The resulting thermal clothing insulation of workers is 0.39 [clo].

Based on observations of work activities and movement of workers respectively energy expenditure was obtained from the classification table, which is included in the standard EN 27243. According to mean energy expenditure from classification table environment is stated as work class 2 . For this class of work is determined by the size of energy expenditure (d'AMBROSIO ALFANO, 2011):

- $\mathrm{q}_{\mathrm{M}}\left[\mathrm{Wm}^{-2}\right]$ - per body surface area $\left(130<\mathrm{q}_{\mathrm{M}} \leq 200\right)$ pertinently,

- $\mathrm{M}[\mathrm{W}]$ - the average body surface area $(234<\mathrm{M} \leq 360)$.

Metabolic expenditure was set at $140\left[\mathrm{~W} / \mathrm{m}^{2}\right]$ which represents 2,41 [Met]. In general, the hot environment is defined as PMV $>+2.0$ (ASHRAE thermal sensation scale - chapter 2). From calculation done in computer program for calculating PMV and PPD obtained results for PMV and PPD were PMV $(\mathrm{M} 1)=3.42$, PMV $(\mathrm{M} 2)=$ 3.66. It can be seen that the measured thermal environment was hot. For evaluating of hot environment, WBGT index was used. The average values of WBGT obtained by statistical processing of measured data for both measurement points were WBGT 
$(\mathrm{M} 1)=33.22\left[{ }^{\circ} \mathrm{C}\right]$ and WBGT $(\mathrm{M} 2)=32.84\left[{ }^{\circ} \mathrm{C}\right]$. When compared with a referential value (refer WBGT $=28\left[{ }^{\circ} \mathrm{C}\right]$ ) found in a table in EN 27243 we can state that WBGT reference value is exceeded.

\section{Discussion}

Exceeding of referential values shows that it is necessary to reduce heat load on workers. There are several ways for doing that (ASHRAE, 2009):

- Apply more detailed analysis of thermal load by more accurate methods,

- Reduce the heat load in a given workplace by using personal protective equipment, adjusting the environment, reduction of time spent in the environment.

For determination of degree of physical human body burden it is necessary to take into account the summary of all thermo-hygric microclimate parameters (high air temperature is worse to bear when there is also a high humidity or air velocity affects the heat transfer between the organism and its environment).

Generally, the more negative factors are in the work environment the greater negative impact they will have on the health of the worker. In this way evaluated facility was designed. Is it possible that because of these factors high values from WBGT were obtained. For a deeper analysis of extremely hot environment, it is recommended to use the PHS index (Predicted Heat Strain) - index of thermal strain, which was developed for the evaluation of transition conditions in hot working environments (EN 27243, 1998).

\section{Summary}

For an indoor air quality study, there are a number of empirical equations used by some authors over the last few years. Indices, such as the predicted percentage of dissatisfied with local thermal comfort, thermal sensation and indoor air acceptability, are determined in terms of some measured parameter, such as dry bulb temperature, relative humidity and speed of air (ISO 7730, 2006).

The problem of high temperatures of air inside industrial workplaces occurs particularly during hot summer days. Assessed workplace showed high dry air temperatures (between $32{ }^{\circ} \mathrm{C}$ and $35^{\circ} \mathrm{C}$ ), and high globe temperatures (between 31 and $40{ }^{\circ} \mathrm{C}$ ). This indicated high level of thermal load, occurred at workplace. By PMV index calculation, it was proved that workers are exposed to thermal stress. The workplace was therefore assessed by WBGT index.

The average values of WBGT were obtained by statistical processing of measured data for both measurement points. Results of statistical processing shows average values of WBGT $(\mathrm{M} 1)=33.22\left[{ }^{\circ} \mathrm{C}\right]$ and WBGT $(\mathrm{M} 2)=32.84\left[{ }^{\circ} \mathrm{C}\right]$. These values were compared with a referential value (refer WBGT $=28\left[{ }^{\circ} \mathrm{C}\right]$ ). From this we can state that WBGT reference value is exceeded. That means it is necessary to reduce the heat load in the given workplace in the future (Buchancova, 2003). 
Kralikova, R.; Sokolova, H.; Wessely, E. \& Polak, J.: Approaches to Assessment of...

Hot summer days are increasing the temperature inside of the building. That is why ventilation and air conditioning systems are common. In many manufacturing plants temperature and humidity are provided by air conditions. If hot industrial facilities are not able to provide air condition they must provide at least natural ventilation (Simonson, 2001).

Nowadays tropical days are more frequent and because of that it is recommended to use air conditioning in hot industrial plants in the future.

\section{Acknowledgment}

This work was supported by project KEGA 032TUKE-4/2012.

\section{References}

American Society of Heating, Refrigerating and Air-Conditioning Engineers (2009). ASHRAE Handbook-Fundamentals, ASHRAE, (SI Edition), ISBN: 978-1 933742-55-7

A. Auliciems, Y. Szokolay, V. Steven, Thermal comfort, (2007). Passive and Low Energy Architecture International Design tools and techniques, Brisbane - The University of Queensland - Department of Architecture, ISBN 0-86776-729-4. F.R. d'Ambrosio Alfano, B.I. Palalla, G.Riccio, (2011). Thermal Environment Assessment Reliability Using Temperature-Humidity Indices, Industrial health, vol. 3, No. 4, pp 95-106. ISSN: 0019-8366

EN 27243: 1998 Hot environments. Estimation of the heat stress on working man, based on the WBGT-index (wet bulb globe temperature)

ISO 7726:2003 Ergonomics of the thermal environmnent - Instruments for measuring physical quantities

ISO 7730: 2006 Moderate thermal environmnent - Determination of the PMD and PPD indicase

J. Buchancova, (2003). Occupational medicine and toxicology, Osveta s.r.o., ISBN 80-8063-113-1, Martin, Slovaki

C.J Simonson, M. Salonvaara, and T. Ojanen, (2001). Moisture content of indoor air and structures in buildings with vapor permeable envelopes, Proceedings of Performance of Exterior Envelopes of Whole Buildings VIII, Atlanta ASHRAE 